\title{
Çocuk Emeğinin Dönüşümü: Ev İçi Üretimden Film Setlerine
}

\author{
Tülay TEKIN-YILMAZ ${ }^{1}$
}

Öz

Çocukların çalışması/çalıştırılması ya da çocuk işçiliği olgusu emek literatürünün içinde yer alan kapsamlı pek çok çalışmanın konusu olmuş ve olmaya da devam etmektedir. Bu durum beraberinde çocuk emeği tarihi ile ilgili olarak zengin bir literarütün oluşmasına katkı sağlamıştır. Ancak kimi araştırmacılar kolektif emekten kopuk bir çocuk emeğinden bahsedilemeyeceğini ve dolayısıyla bu konunun özel bir çalışma veya araştırma nesnesi olamayacağını söylerler. Oysaki üretim biçimleri ve piyasa koşulları ile birlikte değişen emek piyasası dâhilinde çocuk emeği de kendi içinde farklılaşmaktadır. Ayrıca günümüz kapitalizminde pek çok emek biçiminin çıktısının somut ürünler sağlamaması nedeniyle bir çalışma biçimi olduğu da anlaşılamamaktadır. Dolayısıyla emek piyasasının özgül yapısı, bizi yeni iş tanımları yapmaya ve çocuk emeğinden faydalanılan bu alanları açı̆̆a çıkarmaya zorlamaktadır. Bu zorunluluktan hareketle çalışmada günümüz kapitalizminde genel olarak emek piyasasının değişen niteliği ve çeşitlenen emek biçimleri üzerinde durulmaktadır. Bunun yanı sıra çalışmanın ana amacı emek piyasasında yaşanan değişimlere paralel olarak farklılaşan çocuk emeği ve çocukların yaptıkları işlerin aldığ1 yeni biçimleri açığa çıarmaktır. Böylece son yıllarda medya sektöründe reklam ve dizilerde yoğun bir şekilde rol alan çocuk oyuncular, film endüstrisinin merkezi olan İstanbul emek piyasası içerisinde görünür hale getirilecektir.

Anabtar Kelimeler: Neo-Liberalizm, Gayri-maddi Emek, Duygulanımsal Emek, Çocuk Emeği, Çocuk Oyuncular, Film Endüstrisi

\section{Transformation of Child Labor: From Home Production to Movie Sets}

\begin{abstract}
The working of children/child employment or the phenomenon of child labour have been investigated by a number of comprehensive studies within the labour literature. This has contributed to the formation of a rather rich literature on the history of child labour. However, certain researchers suggest that child labour cannot be addressed without its relationship to collective labour, and therefore, it may not constitute a particular field of study or research. Nevertheless, the child labour has also been diversified in itself in a labour market that evolves with the modes of production and the market conditions. Furthermore, various forms of productive activity within the sphere of today's capitalism do not generate tangible goods, and thus, could not be conceived as a way of working. Therefore, this specificity of labour market requires us suggesting new job definitions and revealing such areas that benefit from the child labour. Based on the aforementioned necessity, the present study addresses to the evolving attributes of labour market in general and diversified forms of labour. Besides, the main purpose of the present study is to shed light on the varying forms of the child labour and works performed by children that diversified in parallel to the changes in the labour market. Therefore, the child actors/actresses that were involved recently in the advertisements and TV series within the media industry to an extensive degree, will be made visible within the labour market of Istanbul, the centre of film industry.
\end{abstract}

Key Words: Neo-liberalism, Immaterial Labour, Affective Labour, Child Labor, Child Actors, Film Industry

\section{Atıf İçin / Please Cite As:}

Tekin-Yılmaz, T. (2020). Çocuk emeğinin dönüşümü: Ev içi üretimden film setlerine. Manas Sosyal Araștırmalar Dergisi, 9(2), 1237-1247.

Geliş Tarihi / Received Date: 15.03.2019

Kabul Tarihi / Accepted Date: 28.02.2020

\footnotetext{
1 Öğr. Gör. - Trakya Üniversitesi Roman Dili ve Kültürü Araştırmaları Enstitüsü, tulaytekinyilmaz@trakya.edu.tr ORCID 00000002-9828-1730
} 


\section{Giriş}

Çocuk emeğinin kullanılması her dönemde söz konusu olmuştur. Ancak değişen ekonomik koşullar genel olarak emek piyasasının kökten değişmesine neden olurken diğer taraftan da çocuk emeğinin değişmesine neden olmuş ve de olmaktadır. Ortaçağlarda hane içi üretim aşamasında, küçük atölyelerde yaşlarına uygun işlerde, mesleğin bir sonraki kuşağa aktarılması işlevini yerine getirecek şekilde çalışan çocuklar; bugün birbirinden farklı pek çok üretimin içinde etkin bir şekilde yer almaktadırlar. Sanayileşme ile birlikte ise ortaçağdan farklı olarak yeni bir döneme geçilmiş; çocukların yaptıkları işlerin niteliğinde ve niceliğinde değişimler yaşanmıştır (Aykaç, 2016, s. 336).

Sanayi devrimi ile birlikte kapitalist üretim aşamasına geçilmiş, kitlesel üretim yapmak amaciyla işçi açığı meydana gelmiştir. Bunun yanı sıra nüfusun büyük bir çoğunluğu açlık ve sefalet içerisinde yaşamını sürdürmeye çalışmaktadır. Bu nedenle fabrikalarda çalışacak insanların sayısı artmış; sadece erkekler değil, kadınlar ve çocuklar da fabrikalarda sömürüye açık koşullarda çok zor şartlarda çalışmaya başlamıştır. Bir süre sonra Rönesans ve Reform düşüncelerinin etkileriyle çocuk hakları meselesi gündeme gelmiş, böylece fabrika ortamının çocuklar için uygun bir yer olmadığı, çocukların okula devam etmesinin gerekli olduğu düşünceleri ağırlık kazanmaya başlamıştır.

$\mathrm{Bu}$ dönem aynı zamanda toplum ve aile içerisinde çocuğa bakış açısının kökten değişmesine neden olmuş, çocuk; toplum ve aile için bir sevgi kaynağı haline gelmiştir. Fass (2004) tüm bu değişikliklerle birlikte 19. yüzyılda Batı'nın çocukları pazar ekonomisinden kurtarıp onları bir çeşit masumiyet alanına geçirdiğini söylemektedir. Ancak bugün neo-liberalizmle birlikte yine batıdan tüm dünyaya yayılan tersine bir durumdan bahsetmek zorunludur. Çünkü çocukların günümüzde üretime ve aynı zamanda tüketime katılmalarının sağlanmasıyla yeniden pazar ekonomisine -farklı biçimlerde de olsa- dâhil olmaları ve bu ekonominin sürmesinde aktif rol almaları sağlanmaktadır.

İnal (2010) çocuk işçiliğinin karmaşık bir sorun olduğundan bahseder. Çünkü çok sayıda çocuk yasadışı çalışırken aynı zamanda yaptıkları işlerin çoğu sömürüye dayalıdır. Bunun yanı sıra çocuklar toplumsal, politik, ekonomik, kültürel pek çok farklı nedenle çalıștrılmaktadırlar. İnal çocukların çalıştırılmasını destekleyen politik, ekonomik, toplumsal ve kültürel nedenlerin anlaşılabilmesi için öncelikle çalsşan çocukların hangi işlerde, hangi koşullarda, neden çalsştırıldıklarının anlaşılması gerektiğini de eklemektedir. Bu yaklaşımından hareketle çalışmada öncelikle çocuk emeği tarihinden bahsedilecektir. Daha sonra bugün gelinen noktada, çeşitlenen ve anlaşılması gittikçe zorlaşan emek biçimlerinin analizi, ama özellikle medya sektöründe çalıssan/çalıştırılan “çocuk oyuncular"ın emek analizi yapilacaktır².

Çünkü günümüz piyasasının hem yetişkinler, hem de çocuklar için yarattı̆̆ı yeni çalışma biçimlerinin niteliksel özellikleri, çoğu çalışanın emeğinin gözden kaçmasına neden olmaktadır. Bu durum özellikle maddi ürünler üretmeyen veya çıktısı maddi ürünler olmayan emek türleri için geçerlidir. Özellikle çocuk oyuncuların emeklerinin tamamının ekran arkasında kalıyor olmasına ek olarak görünür olmanın günümüz toplumlarında önemli ve özenilen bir durum olması nedeniyle de çocuk oyuncular birer çalsşan çocuk olarak görülmemektedirler.

Bu nedenle bu çalışma sayesinde Neoliberalizm ile birlikte nicelik ve nitelik bakımından çeşitlenen yeni çalışma biçimlerinin ama özellikle "çocuk oyuncuları" emek kategorisi içerisinde yer almaları sağlanacaktır. Ayrıca çalışmada çocuklar için söz konusu olan bu yeni emek türlerinin özgün biçimlerini tartışmaya açarak durum tespiti yapmanın yanında, aynı zamanda emek-sermaye ilişkilerini düzenleyen iktisadi ve ideolojik yapıları gösteren haritalamayı yapmaya zemin hazırlanacaktır. ${ }^{3}$ Böylece sermayenin özellikle emek üzerinden tüm topluma ve kültürel, aynı zamanda zihinsel yapılara yayılma ve yerleşme süreci anlaşılmaya çalışılacaktır.

\section{Literatür Araştırması}

\section{Çocuk Emeği Tarihi}

\section{Ortaçağda Çocuk Emeği}

Çocuk emeği tarihinin aktarıldığı çalışmalarda çocukların orta çă̆lardan itibaren ekonomik faaliyetlerin içinde yer aldığını görmekteyiz. Ancak çocukların tam olarak hangi işlerde çalıştıklarını ya da çalıştırıldıklarını anlamak oldukça güçtür. Heywood çalışan çocukları "ev dışındaki tam zamanlı işlerden

\footnotetext{
${ }^{2}$ Çocukların medya sektöründe çalıştırılması ile ilgili daha detaylı bilgi için bakınız Tülay Tekin Yılmaz, 2014:211-230

3 Yücesan Özdemir ve Özdemir çalışmalarında söz konusu haritalamanın önemi üzerinde durmaktadırlar.
} 
ufak tefek konularda ebeveynlerine yardıma kadar çeşitli işlerde çalışan, aile ekonomisinin belki de en esnek işçileriydi” diye tanımlamaktadır (Heywood, 2003, s. 149). Çocuklar bu dönemde pek çok farklı işlerde çalısssa da özellikle makinalara dayalı olmayan, genelde aile içinde yapılan ve görece yaşlarına uygun bir çalışma pratiği içinde oldukları görülmektedir. Bu dönemde çocuklar diğer aile fertleri gibi ailenin temel geçim kaynağı olan işlerde ev ekonomisine katkı sağlayacak şekilde çalışmaktadırlar (Dikmen, 1998).

Ayrıca bu dönemde çocukların büyük bir çoğunluğu için çalışma ve eğitimin iç içe geçtiğini görmekteyiz. Çocuklara verilen eğitim onları formel bir çıraklık ya da ev içinde ve tarla işlerinde beceri isteyen görevleri yaparak yetişkinlerin çalışma/iş dünyasına girmelerine hazırlayan türden bir eğitim biçimidir (İnal, 2007a, s. 30). Bu nedenle bu dönemde çocukların çalışması aynı zamanda onların eğitilmeleri anlamına da gelmektedir. Bunun yanı sıra çocukların çalışması toplumun yeniden üretimi işlevini yerine getiren pek çok zanaatın bir sonraki kuşağa aktarılmasını sağlamaktadır. Bir yakınının yanında ya da babasının veya akrabasının yanında çırak olarak çalışan çocukların aynı zamanda mesleğin (zanaatın) bir sonraki nesle aktarlması işlevini de yerine getirmektedir (İnal, 2010, s. 13).

Ortaçağlarda çocuklar çırak-kalfa-usta birlikteliği şeklinde oluşan mesleki kuruluşlar olan Loncaların aktif birer üyesiydiler. Yıldıım (1998) başlarda oldukça etkili bir şekilde çalışmalarını sürdüren bu Lonca birliklerinin bu dönemin sonlarına doğru bozulmaya başladığına değinmektedir. Loncalara girişin katı kurallara bağlanması ve her birinin adeta bir tekel halini alması Lonca birliklerine girişi zorlaştırmış ve süregelen düzenin bozulmasına neden olmuştur. Sanayileşmenin artması ve kapitalist üretim biçiminin başat üretim biçimi haline gelmesi ile birlikte Lonca birlikleri kapitalizmin gelişmesinin önünde bir engel olarak görülmüş ve yasaklanmıştır.

\section{Sanayilessme Sürecinde Çocuk Emeği}

Sanayi Devrimi olarak adlandırılan bu süreçte tüm toplumların sosyal, ekonomik ve siyasal yapılanmalarında kökten değişiklikler yaşanmıştır. Ancak görünürde en temel değişiklik insan emeği üzerinde yaşanmıştır. Bu dönemde yaşanan ekonomik değişme ve büyüme büyük bir işgücüne gereksinim doğurmuştur. Böylece daha kolay sömürülebilecek, itaatkâr ve uysal bir emek biçimi olan kadın ve çocuk emeği de kapitalist üretime dâhil edilmişlerdir. (Yıldırım, 1998). Çünkü kadın ve çocuklara ödenen ücretler erkek işçilere ödenenden çok daha düşüktür.

Dikmen (1998) kadın ve çocukların fabrikalarda üretim maliyetini düşürmek açısından ekonomik değişimin en önemli elemanları haline geldiklerinden bahsetmektedir. Bu nedenle çocuklar on dokuzuncu yüzyıl ortalarına kadar artan bir oranda fabrikalarda çalıştırılmışlardır. Ayrıca değişen piyasa koşullarının yeni iş alanları yaratması ve bu alanlarda çalışacak çok sayıda işçiye ihtiyaç duyulması da çocukların ve kadınların kapitalist işletmelerde çalışmasının bir diğer nedenidir. "Özellikle maden ocaklarındaki dar tünellerden çocukların kolaylıkla geçebilmeleri ve tekstil alanında da kadınların el becerilerinin erkeklere oranla daha üstün olması, fabrika sahipleri yönünden, kadın ve çocuk işçi çalıştırmayı çekici hale getirmiştir." (Yıldırım, 1998, s. 1).

Ancak tüm bunların yanında toplumun büyük bir oranının yoksulluk içinde yaşamanı sürdürüyor olması da fabrikalarda iş piyasasının ihtiyacından daha fazla kişinin çalışmaya hazır hale gelmesine neden olmuştur. Heywood (2003) bu dönemde özellikle çocukların çalışmaya başlamasının aile ekonomisine sanıldığından daha fazla katkı sağladığını göstermek amacıyla çok sayıda incelemeden örnekler aktarmaktadır. Bu incelemelerden birinde 1830'larda Rouen'de el tezgâhında dokumacılık yapan dört kişilik bir ailenin temel ihtiyaçlarını karşılamak için senede 912 frank kazanması gerektiği hesaplanmış, ancak bu meslekte çalışan erkek ve kadınların ortalama ücretlerinin sadece 861 frank olduğu söylenmiştir. Böyle bir durumda karı kocanın en düşük gelir seviyesine ulaşabilmesi için bile ortalama kazancın üzerinde bir paraya ihtiyacı olduğu görülmüştür.

İşte bunun gibi çok sayıda örnekte gösterildiği üzere çocuklar ailenin gelirinin yeterli olmadığı bir dönemde fabrikalarda çalışmaya başlamış ve kitlesel üretimin bir parçası haline gelmiştir. Daha önce evlerde veya küçük atölyelerde görece kendilerine uygun işlerde çalışırken endüstri devrimi ile birlikte daha zor şartlarda ve sömürüye açık koşullarda çalışmaya başlamışlardır. İnal bu durumu şöyle anlatır: Ortaçağın kırsal kültür ve toplumlarında çocuk, ağırlıkla tarımsal işlerde ama daha çok aile/hane ekonomisi içinde iş görürken sanayileşmeyle birlikte fabrika, maden ve atölye tipi yoğun, tehlikeli, sağlıksız ve yetişkin tacizine/baskısına açık iş yerlerinde yeni tip işverenlerin (tüccar, sanayici vd.) adına çalışmaya başlamıştır. Böylece yüzlerce yıl sıradan, önemsiz ve değersiz görülen çocuk emeği, kapitalist sanayileşmeyle birlikte piyasada önemli bir kategoriye (çocuk işçi/emekçi) dönüşmüştür. (İnal, 2007b, s. 330). 
19. yüzyllın çocuk emeği sömürüsünün boyutu açısından diğer dönemlerden radikal bir biçimde ayrıldığını vurgulayan İnal çocuklar için, en azından çaresiz ve yoksul çocuklar için bu yüzyıllın bir karabasan olarak tanımlar (İnal, 2010, s. 15). Ancak yine bu dönemde Rönesans ve Reformun etkisiyle şekillenen üst ve orta sınıflara özgü yeni çocukluk ideolojisiyle birlikte, çocuğun yerinin fabrika değil okul olduğu yönünde fikirler de ortaya çıkmaya başlamıştır. Bu tarihten önce çocuklar cemaatin dar ve sınırlayıc1 ilişkileri içinde dine göre şekillendirilmekte ve üretim alanlarında bir emek kaynağı olmak dışında çok fazla anlamları bulunmamaktadır.

Fransız Devrimi sonrasında ise toplumsal gelişmenin çocuğun bireyselleşmesi ile birlikte sağlanacağı inanc1 yayılmaya başlamıştır. Bu nedenle kentleşme ve sanayileşmeyle birlikte orta ve üst sınıf ailelerde çocuklarla daha özenli ilgilenilmiş ve bilgiyle biçimlendirilmişlerdir. Dolayısıyla bu dönemde çocuklar ekonomik değil psikolojik; şefkat kaynağı olarak görülmeye başlanmışır. Ancak İnal bu değişimin en temel sebebini çocukları üzerinden anne-babaların bir statü edinmeleri talebi olduğuna bağlar. Bu yüzdendir ki ileride yer alacakları mesleki hayat için daha iyi eğitilmeleri gerekmektedir. Böylece çocukların yeri fabrikalar değil okul olarak görülmeye başlanmıştır (İnal, 2010, s. 18).

Çocuklar ve çocukların çalışması ile ilgili inanışlarda yaşanan değişimler ve bu konuda verilen toplumsal mücadelelerin 19. yüzyılda çocukların ekonomik gerçeklik boyutundan duygusal gerçeklik boyutuna geçmesinde payı büyüktür. Bu durum beraberinde çocuğun değeri ile ilgili anlayışlarda öncekilerden oldukça farklı bir takım değişikliklere neden olmuştur. Batı, çocukları açgözlü pazar ekonomisi makinasından kurtarıp onlara öncekinden farklı bir değer verip yatırım yaparak, çocukluğu bir masumiyet alanı içine yerleştirmiştir. Ancak böylesine bir değer değişiminin özellikle Birleşik Devletler ve Batı toplumlarında yaşayan çocuklar için daha genellenebilir bir olgu olduğu da gözden kaçırılmamalıdır (Fass, 2004, s. 144-145).

Çocuğa verilen değirin değişmesi ile birlikte çocukların çalışma koşulları ve çocuk hakları gibi meseleler de tartışmaya açılmıştır. Yücesan-Özdemir, Özdemir merkez ülkelerde on dokuzuncu ve yirminci yüzyllarda sosyal politika alanındaki toplumsal mücadelenin ana eksenini çocuk emeğinin sınırlandırılması ve düzenlenmesine yönelik çalışmaların oluşturduğundan bahsederler. Dünya üzerinde kapitalizmin eşitsiz gelişme yasası doğrultusunda zenginliğin merkezde birikmesi, bu zenginliğe koşut teknolojik gelişmişlik düzeyi, emek verimliliğinin dünyanın diğer bölgeleri ile kıyaslanamayacak kadar artmasına neden olmuştur. Kapitalizmin 'altın çağı' denilen dönemdeki sosyal refah devleti uygulamaları ve bu ülkelerde yaklaşık 200 yıllık işçi sınıfı mücadelesi, merkez ülkelerin çocuk emeğini sınırlayıcı ve koruyucu düzenlemelere sahip olmasını sağlamıştır (Yücesan-Özdemir, Özdemir, 2010, s. 142).

\section{Neoliberal Dönemde Çocuk Emeği}

Yirminci yüzyıla gelindiğinde sermaye piyasasında yaşanan değişimlere paralel olarak emek piyasasında ve dolayısıyla çocuğun algılanmasında farklı bir yola girilmiştir. Çünkü bugün çocuklar günümüz piyasa koşulları içerisinde etkin bir şekilde yer almaktadırlar. Yirminci yüzyılın son çeyreğinde küresel piyasanın, yeni liberal dogmanın artan egemenliği çocuk işçiliğinin, on dokuzuncu yüzyıldakine benzer ağır bir insani ve sosyal sorun haline gelmesine neden olmuştur (Çelik, 2010, s. 55). Dolaysıyla Fass'ın ve İnal'ın 19. yüzyılda Batı'nın çocukları pazar ekonomisinden kurtardığı ve onları ekonomik değil bir şefkat kaynağı haline getirdiği yönündeki tespitlerinin bugün için artık geçerliliğinin kalmadığ1 düşünülmektedir. Çünkü yirminci yüzyıl ve sonrasında güçlenen sermaye on dokuzuncu yüzyılda çocuğa karşı gelişen toplumsal hassasiyetleri kendi lehine kullanmaya başlamıştır.

Çocuğun ailenin ve toplumun geleceği için öneminin fark edilmesi -genelde batı toplumlarından başlayarak- çocuğun değerinin artmasına neden olmuştur. Hemen her durumu kendi kazançlarını arttırmaya yönelik bir araç olarak gören sermaye sahipleri çocuğun toplum ve aile içinde kazandığı bu yeni gücü de kullanmayı becermiştir. Böylece "neoliberal dönemde çocuk, sermaye için ucuz işgücü olmanın ötesine geçerek, eğitim, sağlık, giyinme, oyuncak ve teknoloji gibi alanlarda yeni bir pazar öğesi haline gelmiştir" (Kavili Arap, 2016, s. 159)

Bin dokuz yüz yetmişli yllardan itibaren özellikle Amerika ve Avrupa ekonomisinde baş gösteren aşır1 sermaye birikimi bir sorun olarak gündeme gelmiş, atıl kalan sermaye fazlalarının yatırım yapacağı yeni iş alanlarına ve sermayenin maksimum gelir elde edebilmesi için maliyeti düşük girdilere ihtiyaç duyulmuştur. $\mathrm{Bu}$ nedenle aşırı birikmiş sermayenin dünyanın genelinde yatırım yapabilmesinin önündeki engellerin kaldırılmasına dayalı bir ekonomi politik anlayışı IMF ve Dünya Bankası aracilığıla tüm dünyaya yayılmaya başlamıştır (Harvey, 2004, s. 131). Yücesan-Özdemir ve Özdemir bu durumun birinci işbölümü olarak 
tanımlanan ve merkezin çevre ülkelerden işgücü ve hammadde alıp karşılığında mamul verdiği klasik merkez-çevre ilişkisini değiştirdiğini söylemektedirler. Bu değişimle birlikte ikinci işbölümü dönemi başlamış merkez ülkelerdeki aşırı sermaye ve sanayi üretimi çevre ülkelerdeki ucuz emeğe yönelmiştir.

Bunun yanı sıra kapitalizmin uluslararası kurumları da ilgili ülkeleri birbiri ile ucuz emek rekabetine sokacak şekilde bu yatırımları düzenlemiştir. Anılan süreçte sermaye emek arasındaki ilişkide güç dengeleri yeniden belirlenmiş, bireysel kapitalistler işçinin karşısında, işe alıp çıkarma ve çalışma saatlerinin süresinin ve başlangıç ve bitişini saptama konuları başta olmak üzere, yeni güçlerle donanmışlardır. Bunun neticesinde, bir bask1 aracı olarak piyasa kurumu; en savunmasız, en itaatkâr ve en uysal emek gücü olan çocukları ve genel olarak toplumun bütününü yeni sermaye ilişkisinin gereklilikleri doğrultusunda biçimlendirmiştir (Yücesan-Özdemir ve Özdemir, 2010, s. 143).

Lazaratto (1996) da toplumun bütünün yeni sermaye ilişkilerinin gerekleri doğrultusunda biçimlendirildiğine benzer bir tespitle toplumsal ilişki ve iletişimin kapitalist üretim sürecinin bir parçası haline geldiğinden bahsetmektedir. Çünkü 1970'lerden itibaren üretim fabrikanın dışına taşarak sadece nesneler değil hizmet, bilgi ve iletişim gibi ölçülemez şeyleri üreten bir emek türü haline gelmiştir. Lazaratto bu yeni emek biçimini gayri maddi emek olarak tanımlamaktadır ve bu emek biçimi sadece mallar değil ama ilk olarak ve her şeyden önce toplumsal ilişkiler üretmektedir. Maddi olmayan emeği "malların bilişsel ve kültürel içeriğini üreten emek" olarak tanımlamaktadır (Lazzarato, 1996, s. 133).

Hard ve Negri (2004) de gayri maddi emek üzerine oldukça geniş çalışmalarında maddi-olmayan emeğin bir biçimi olarak duygulanımsal emekten bahsetmektedirler. Ancak duygulanımsal emek tartışmalarına geçmeden önce, "duygulanım" sözcügünün ne anlama geldiği üzerinde durmak gerekmektedir. "Sözcük esas anlamını, bireyde kısa süreli, geçici ve anlık gözlemlenebilir duyguların oluşması anlamına gelecek şekilde psikoloji alanından almış olmakla birlikte, sosyal bilimlerin farklı alanlarından araştırmacıların ilgisini çeken bir kavramsallaştırma olarak karşımıza çıkmaktadır.

Sözcügün özellikle Deleuz ve Guattari tarafindan felsefe ve siyaset bilimi alanında kullanılması, anlamının genişlemekte olduğunu göstermektedir" (Emirgil, 2010, s. 229). Akalın da Emirgil gibi kavramın psikoloji alanından alınarak siyaset bilimi içerisinde kullanılmakta olduğuna değinmektedir. Duygulanım kavramı psikoloji alanında insan dürtülerinin doyuma ulaşmasında yardımcı rol oynayan durumlar için kullanılmaktadır. Mesela "acıkma hissine eşlik eden bir heyecanlanma (ve belki bunun acıkma hissini artırması) ya da bunun tam tersine, iğrenme hissi ile iştahın kapanması gibi. Burada görüldüğü üzere dürtü acıkma hissi, iğrenme ve heyecanlanma ise yardımcı rolü oynayan duygulanımlardır".

Ancak duygulanım kavramı siyasi teorinin içinde yardımcı bir kavram olarak karşımıza çıkmamaktadır. Spinoza'dan aldıkları kavramı daha geniş bir anlamda kullanan Deluez ve Guattari; bu kavramın duygulardan farklı, bir çeşit bedenler arası anlam yaratma aracı olarak düşünülmesi gerektiğini savunurlar. Duygulanımın somut, sayılabilir ya da görünür bir şey olmaktan ziyade, bir dolaşım hali olarak hayal edilmesi beraberinde kavramın tanımlanmasını da zorlaştırmaktadır. Duygulanımsal emek ise günümüz toplumlarında her tür üretim biçimine sirayet etmiştir. Bedensel bir üretim biçimidir ama üretimin sonucunda ortaya çıkan ürünler maddi halden, çeşitli biçim ve düzlemlerde oluşan ilişkisellikleri içeren durumlara kadar farklı soyut hallerdir (Akalın, 2007). Bu türden bir emek biçiminde duygunun yaratılması ve manipülasyonu söz konusudur.

Hard ve Negri (2004) özellikle yirminci yüzyllın son on yllında emek süreçlerinde yaşanan değişimlerle birlikte maddi ürünler üreten emek biçimlerinin yanında duygulanımsal emek biçimlerinin de arttığına dikkat çekmektedirler. Duygulanımsal emek bilgi, enformasyon, iletişim, ilişkiler veya duygusal ifade gibi maddi olmayan ürünlerdir ve sermaye bu emek sayesinde ortak ilişkiler ve ortak toplumsal biçimler yaratarak tüm toplumu kendi imajina göre dönüştürmektedir. Hard (1999) maddi olmayan emeğin bir yüzü olarak tanımladığ1 duygulanımsal emeğin eskiden beri var olduğuna dikkat çekmektedir. Özellikle feministlerin analizlerinde karşımıza çıkan ve kadın bakım görevleri olarak adlandırabileceğimiz akraba bakımı, beslenme, anne faaliyetleri gibi duygulanımsal emek türleri toplumsalın yeniden üretilmesinde önemlidirler.

Ancak günümüz çağdaş bilgi ekonomisinde duygulanımsal emek en yüksek değere hâkim bir konuma sahiptir ve özellikle hizmet endüstrisinde karşımıza çımaktadır. Bu emek türünün fast-food sunucularından finansal hizmetler sağlayıcılarına kadar insan etkileşimi ve iletişim anlarında gömülü bir rolü vardır. Bedene dayalı maddi ve mantıklı bir yapısı olsa bile, ürünlerinin somut olmaması nedeniyle önemsiz görülür. Oysa rahatlık hissi, memnuniyet, heyecan, tutku-bağlllık, topluluk hissi gibi duygular 
üreterek bireylerin ruhlarını biçimlendirmektedir. Bu da genel olarak bu emek biçiminin sosyal ağlar, toplumsallaşma ve biyogüç üretmesi anlamına gelmektedir.

Biyogüç, yaşamın yaratılmasının gücüdür; kolektif öznelliklerin, sosyalliğin ve toplumun kendisinin üretimidir. Hard için bu emek biçiminin bu kadar önemli olmasının nedeni; sermaye tarafından manipüle edilerek tüm emek ve toplum yapılarının özüne sızması ve duygu üretimi aracıllı̆ıyla yaşamı şekillendiriyor olmasıdır. Sonuç olarak endüstriyel dönemde maddi emek biçimlerinin metalaşması söz konusuyken, postfordist olarak adlandırılan endüstri sonrası dönemde ise maddi-olmayan emek biçimlerine ait kültürelbilişsel ürünlerin ve duygulanımsal çıktıların metalaşmasına tanık olmaktayız (Emirgil, 2010, s. 234). Duygulanımsal çıktıların metalaşması demek aynı zamanda duyguların metalaşması demektir ve bu metalaşa hali işyerini de aşarak tüm yaşama sirayet etmektedir. Böylece bu emek sayesinde her tür toplumsal ilişki ve iletişim artık kapitalist üretim sürecinin bir parçası haline gelmiş ve emek tümüyle sermayeye tabii olmuştur (Yücesan-Özzdemir, 2014, s. 117-119).

Sermaye her dönemde toplumsal yaşamın üretimini, yeniden üretimini ve kontrolünü sağllyorken bugün bu emek sayesinde hiç olmadığı kadar açık ve doğrudan bir biçimde bunu yapmaktadır. Fabrika duvarlarını aşarak tüm kent yaşamına yayılan ve çıktısı ile somut ürünler sağlamayan bu emek biçiminin esnek yapısı sermaye sahibinin emek üzerinde sömürüsünün artmasına imkân sağlamaktadır. Çünkü yukarıda sayılan özelliklerinden dolayı aslında bir emek olduğu bile anlaşılamamaktadır. Ayrıca bu yeni emek biçimi, kapitalist işverenin çalışma süresini istediği şekilde ayarlama gücünü elinde bulundurmasından dolayı; keyfiliğe, hareketliliğe ve hiyerarşiye dayanmaktadır (Özgün, 2007, s. 3). Son dönemlerde yaşanan emek süreçlerindeki bu değişimler hiç kuşkusuz ki çocuk emeğinin de değişmesine neden olmaktadır.

\section{Türkiye'de Bugün Çocuk Emeği}

\section{Çocuk Emeğindeki Değissimler}

Bu süreçte ülkemizde tarihin uzun dönemlerinden beri var olan bir olgu olarak karşımıza çıkan çocuk emeğinin eski biçimleri devam ederken beraberinde yeni biçimlerin de ortaya çıktığ1 görülmektedir. "Görece geniş bir tarımsal ve enformel sektöre sahip olan Türkiye'de çocuk emeğinin tüm tezahürlerini yakalayabilmek için 'iş’ olgusunu değişen sosyo-ekonomik koşullara göre kapsam ve değer bakımından farklılaşan dinamik bir süreç olarak anlamak önemlidir" (Ertürk, 2010, s. 29). Çünkü enformel sektörün ve geçimlik ekonominin söz konusu olduğu günümüzde emek çerçevesinde "iş" ve "iş olmayan" tanımlamalarının birbirine girdiği görülmektedir.

Ayrıca bir önceki bölümde bahsedildiği üzere günümüz ekonomisinde gittikçe yaygınlaşan bir emek biçimi haline gelen gayri maddi emek biçimleri çıktılarının soyut olması nedeniyle ya iş olarak kabul edilmemekte, ya önemsenmemekte ya da görmezden gelinmektedir. Buradan hareketle hanenin geçiminde önemli bir yere sahip olmasına rağmen görmezden gelinen veya iş olarak kabul edilmeyen pek çok çocuk üretiminin "iş" olarak kabul edilip tanımlanması oldukça önemlidir. Ertürk'ün "iş" olgusunun değişen sosyo-ekonomik koşullara göre dinamik bir süreç olduğu saptamasından hareketle ve ona ek olarak çocukların yaptıkları işleri anlayabilmek için sadece tarımsal ve enformel sektörlere bakmanın bugünün piyasa koşulları için yetersiz olduğu düşünülmektedir.

Emirgil küresel ve esnek bir örgütlenme yapısına sahip olan sermayenin emeğin niteliğini, içeriğini ve anlamını değiştirdiğine, dönüştürdüğune hatta çeşitlendirdiğine değinir. "Hem nicel (yeni işlerin ve mesleklerin) hem de nitel (mevcut işlerdeki vasıfların ve becerilerin değişmesi ) boyuttaki değişimler, hızla büyüyen meslek grupları olan profesyonellerin ve hizmet işçilerinin emek piyasası içerisinde istihdam oranlarının artmasına neden olmuştur" (Emirgil, 2010, s. 225). Bu yeni dönemi ve bu dönemin çocuk emeği üzerindeki değişimini anlayabilmek için özellikle medya sektörüne bakmak yerinde olur. Çünkü kapitalist bir sosyo-ekonomik düzen içerisinde olmazsa olmaz bir eleman olan medya, dünyanın belli merkezlerinde yeni bir çocuk emeği biçiminin oluşmasına sebep olmuştur.

Küreselleşme veya neoliberalizmle birlikte değişen emek piyasası İstanbul gibi dünyanın bazı merkezlerinde yer alan medya sektöründe, çocuk oyuncuların yoğun bir biçimde kullanılmasına neden olmuş ve böylece çocukların yaptıkları işlere bir yenisi daha eklenmiş̧ir. Türkiye özelinde düşündüğ̈̈müzde bazen Ankara'da çekilen diziler olsa da bu örnekler İstanbul'un merkez olma özelliğini değiştirecek oranda değildir. Reklam, dizi ve filmlerin çekildiği yerlerin İstanbul olması ve bu nedenle sektöre iş gücü sağlayan reklam ajanslarının burada bulunması -kısaca film endüstrisinin merkezinin İstanbul olması- İstanbul'a özel bu emek biçimini yaratmışır. Ancak kapitalizmin yükselişiyle beraber medyanın ve televizyonun giderek yaygınlaşmasıyla birlikte gündeme oturan çocuk oyuncuların yaptıkları 
işin kendine özgü karakteri nedeniyle aslında birer çalısan çocuk olarak tanımlanmaları ya da o gözle değerlendirilmeleri pek mümkün olamamaktadır.

Değirmencioğlu medyanın aracılı olması yani dolayll1ık özelliğine sahip olması nedeniyle toplumun aldatıcı, yanılıcı görüntüler ile duyarsızlaştı̆̆ını ya da çok az farkındalık sahibi olduğunu söylemektedir. Ekrandaki çocukların görüntülerinin özellikle sevimli, güzel, dikkatle seçilmiş ve makyajlanmış olarak gösterilmesi; gerçekliğin dolaylı ve çarpıtılarak sunuluyor olması; beğenilir olma, prestij ve ünlülük durumunun cazibesi toplumun geri kalanları için bir çeşit sis perdesi oluşturmaktadır. Bu da beraberinde çocukların çalışıyor olduğu gerçeğinin gözden kaçmasına neden olmaktadır. Değirmecioğlu'na ek olarak çocukların çalışıyor olduğunun gözden kaçmasının bir diğer nedeni ise bu çocukların somut ürünler üretmiyor olmalarıdır. Bu nedenle Hard'ın (1999) dediği gibi somut çıtıları olmayan gayri-maddi emek biçimleri, çocuk oyuncuların durumunda olduğu gibi, ya görmezden gelinir ya da önemsiz kabul edilir.

Tekin-Yılmaz (2014) çocuk oyuncular üzerine yaptığ çalışmasında medya sektöründe çalışan çocukların emek çıktılarının niteliğinin yanı sıra çalışma koşulları açısından da gayri maddi emek ürettikleri üzerinde durmaktadır. Söz konusu çocukların esnek çalışma saatleri, düzensiz iş yapıları ve sahne arkasında kalan, dolayısıyla da bir iş olduğu anlaşlamayan çalışma biçimleri ile günümüz neo-liberal piyasa koşullarına uygun bir emek üretiminde bulundukları çok açıktır. Görüldüğü üzere bu çocukların çalışıor olmalarının yanında yaptıkları işin niteliğinin ya da ürettikleri ürünün çıktısının da tartışılması önemlidir. Çünkü bu iş sayesinde çocuklar toplumun değer yargılarını, alışkanlıklarını ve genel olarak hayatı algılama ve yaşama biçimlerini sermaye sahipleri lehine yeniden üretme görevini görmektedirler. Böylece tüm toplumu günümüz kapitalizmine uygun bireyler haline gelmelerine hizmet eden çocuk oyuncular Hard ve Negri'nin tanımladıkları duygulanımsal emek kategorisinde yerlerini almaktadırlar.

\section{Çocuk Oyunculann Tanımlanması}

Erder (2010) İstanbul'da çalışan çocukları 4 gruba ayırmıştır. Bunlar; ekmek parası için çalışan mutlak yoksullar, meslek arayan çıraklar, yeni çocuk işçiler: kız çocukları, okulda başarısız olan çocuklar. Erder'in İstanbul özelinde yapmış olduğu bu sınıflandırmaya bugün çocuk oyunculardan oluşan beşinci bir grubu eklemenin gerekli olduğu düşünülmektedir. Çünkü bu çocukların hem çalışarak yani üreterek, hem de yaptıkları işin çıktısıyla toplumda tüketim kültürünün yayılmasını teşvik etmelerinden dolayı neoliberazlimin en güçlü motorlarından birisi haline gelmektedirler. Ayrıca Erder dünyada çocuk işçileşmesinin genel olarak belli sebeplere bağlanmasına değinmiş ve bu genel tespitlerin Türkiye için de geçerli olduğunu söylemiştir. "Çocuk işçileşmesinin genel olarak nüfus artışının fazla olduğu, köylülükten çıkan, küreselleşmenin de etkisiyle, düşük hünerli işgücünü yaygın olarak kullanarak üretim yapan, yoksulluk açısından kutuplaşmanın arttı̆̆ toplumlarda yaygınlaştığı" (Erder, 2010, s. 42) üzerinde durmaktadir.

Türkiye'de de benzer bir şekilde çalışan çocukların yoksul ailelerden gelmesi nedeniyle çocukların işçileşmesinin yoksullukla bağının kurulması gerektiğini de eklemektedir. Ancak Erder yoksulluğun göreli bir kavram olduğu ve çalışan çocukların yoksulluk derecesi açısından homojen olmadıkları gibi nedenlerden dolayı meseleyi sadece yoksullukla açıklamanın yetersiz olacağını söyleyerek bu çocukları çalışma nedenleri açısından 3 kategoriye ayırmaktadır: Birinci gruptakiler "ücretsiz aile işçisi” olarak çalışan gruptur. Bunlar geleneksel olarak eskiden beri aileleri için çalışması gerektiği düşünülen çocuklardır ve zaman zaman bunu para karşılığı başkaları için yapmaları da yadırganmamaktadır. Hatta bunun için yoğun bir toplumsal baskı da söz konusu olabilmektedir. İkinci grutakiler "çıraklık" kurumunda yer alan gruptur. Bu grup özellikle kırdan kente yeni göç etmiş ya da kent yoksulları için yine oldukça eski bir kültürel kabulün ve güvenin sonucunda belli mesleklere girişi kolaylaştıran bir süreç olarak görülen çıraklık mesleğini icra eden çocukların oluşturduğu gruptur.

Üçüncü gruptakiler ise artan tüketim isteği nedeniyle çalışan çocuklardan oluşan bir gruptur. Kitle iletişim araçları, ama özellikle televizyon ve reklamlar toplumun genelinde 'tüketim' arzusunu arttıran bir etkiye neden olmaktadır. Bu istek yoksulluğa dayanmanın bir değer olduğu geleneksel inanışı yok ederek yerine daha fazla tüketmeyi bir değer olarak koymaktadır. Bu durum aynı zamanda genel olarak toplumda çalışmanın anlamını da değiştirmiş, çalışmak tüketmek için yapılan bir faaliyete dönüşmüştür. "Bu yeni anlayış, daha önce var olan, 'hüner edinmek', 'meslek edinmek' ya da 'geleceğini garantiye almak' için çalışmak anlayışının yanına yerleşmeye başlamıştır.”

Erder’in bıraktığı yerden devam edecek olursak medyada çalışan/çalıştırılan çocukların üçüncü grup içinde değerlendirmeleri gerektiği düşünülmektedir. Ayrıca söz konusu çocukların temsil ettikleri 
değerlerin, tüketimi yayma özelliği nedeniyle, daha çok tüketmek amaciyla çalışacak/çalıştırilacak çocukların sayılarının artmasında bir etken olabilecekleri de çok açıktır. Çünkü Rapport and Meleen'in (1998) de belirttiği gibi çocuk oyuncular geniş kültürümüzün sözcüleri ve rol modelleri olarak hizmet ederler ve onların tutumları psikososyal uyumları medyanın etki alanındaki kişilere yansımaktadır. $\mathrm{Bu}$ durumda medya sektöründe ekranın önünde rol alan çocuk oyuncular hem görünürlükleri hem de yaydıkları değerler açısından onları izleyen anneler ve çocukları için birer model oluşturmaktadırlar. Böylece medyanın adeta büyülü etkisiyle bu çocukları izleyenler için onlar gibi olma ve/veya onların temsil ettikleri hayat biçimine ulaşma isteği yaratılmış olmaktadır. Ancak hemen eklemek gerekir ki çocukların çalıştırılmasını veya çalışmasını daha çok tüketmek isteğine bağlamak çalışan çocuklarla ilgili tespitleri onların ve ailelerinin bireysel seçimlerine indirgeme tehlikesini içinde barındırmaktadır.

Yücesan-Özdemir, Özdemir benzer bir uyarıda bulundukları yazılarında egemen söylem tarafindan çocukların çalışmalarının yoksulluk, gelir dağllımındaki eşitsizlik, bölgeler arasındaki eşitsizlik, iç göç ve çarpık kentleşme gibi nedenlere bağlandığına değinmektedirler. Ancak bu olgular çocuk emeği kullanımının nedenleri değil; tüm emek sömürüsünün kapitalist biçiminin görüngüleridir. Yani yoksulluk, eşitsizlik, iç göç ve nihayetinde çocuk işçiliğinin nedenleri aynıdır ve bu nedenler iktisadi, siyasi ve ideolojik mekanizmalar tarafından oluşmaktadır. Sonuç olarak bu mekanizmaları tartışmak yerine çocuk emeğini bireysel seçimlerden hareketle açıklayan çalışmaların bu olguyu ebeveynlerin tembelliği ve sorumsuzluğuna bağlayacak kadar cüretkâr davrandıklarını da eklemektedirler. Çünkü böylesi bir yaklaşım günümüz neoliberal/küresel kapitalizminin topluma yaymaya çalıştı̆̆ bireyselliğin bir uzantısı olan, tüm olguların bireysel seçimler sonucu oluştuğu yönündeki düşünceyi tekrar etme tehlikesini içinde barındırmaktadır (Yücesan-Özdemir, Özdemir, 2010, s. 136).

\section{Yöntem}

\section{Çalışmanın Amacı ve Önemi}

Daha önce de bahsedildiği üzere neoliberalizm ile birlikte emek biçimleri nicelik ve nitelik bakımından oldukça değişik biçimlerde karşımıza çıkmaktadır. Hatta emeğin bu değişken yapısı nedeniyle birçok çalışma biçiminin gözden kaçtı̆̆, çalışanların emeğinin görünmediği ve bazen yapılan işin bir çalışma biçimi olduğunun bile anlaşllamadığı durumlar söz konusudur. Çünkü bu günün emek biçimleri daha önce de belirtildiği gibi somut ürünler üretmediğinden birer çalışma biçimi olduğu da anlaşılamamaktadır. Bu nedenle çalışmanın amaçlarından birisi öncelikle değişen emek biçimlerinin nasıl olup da birer emek olarak kabul edilmediğini anlamaya çalışmaktır.

Bu duruma en güzel örnek medya sektöründe rol alan çocuk oyunculardır. Bu çocuklar harcadıkları emeğin ekran arkasında kalmasi; somut bir ürün üretmemeleri ve üstelik toplumun geneli tarafindan özenilen figürler olmaları nedeniyle çalş̧an çocuk kategorisinde zikredilmemektedirler. Sonuç olarak çalışmanın amaçlarından biri genel olarak günümüz neoliberal toplumlarında değişen emek biçimlerini analiz etmek olsa da bir diğer amacı özellikle çocuk oyuncular örneğinden hareketle çocukların yaptıkları işlere bir yenisinin eklendiğini gösterebilmek ve onları çalışan çocuk kategorisinde değerlendirilmelerine ön ayak olmaktadır.

Dolayısıyla çalışmanın önemi; bu yeni dönemde çeşitlenen yeni çalışma biçimlerinin emek kategorisi içerisinde anılmasını sağlarken aynı zamanda çocuk emeğinin tüm yasal düzenlemelere rağmen önlenemediği ve hatta yenilerinin eklendiğinin de ortaya koymasıdır. Çalışmanın bir diğer önemi ise; İnal'ın da belirttiği gibi çocukların bu türden bir işi yapmalarına neden olan politik, ekonomik, toplumsal ve kültürel süreçleri ortaya çıkaracak yeni çalışmaları tetikleyecek olmasıdır.

\section{Çalışmanın Yöntemi ve Sınırları}

Bu amaç doğrultusunda çalş̧mada "literatür taraması" yönteminden yararlanılmış; yerli ve yabancı kaynaklarda genel olarak emeğin, özel olarak ise çocuk emeğinin değişim ve dönüşüm süreçleri araştırılmıştır. Bugün gelinen noktada emek süreçlerinde yaşanan bu değişim ve dönüşüm beraberinde yeni emek biçimlerini de tanımlamayı zorunlu kılmaktadır. $\mathrm{Bu}$ çalışma bu türden bir tanımlama zorunluluğundan hareketle ortaya çıkmıştır. Ancak çalışma değişen ve dönüşen çocuk emeği türlerinden sadece medya sektöründe çalışan/çalıştırılan çocukların tanımlanmasını sağlamaktadır. Oysa bu yeni dönemde daha önce de belirtildiği gibi gizlide kalmış pek çok çalışma biçimi mevcuttur. Ancak söz konusu bu tartışmaları bir makaleye sığdırmak imkânsız olduğundan bu çalışmayı belli bir kapsamda sınırlandırmak gerekmiştir. 


\section{Araştırma Bulguları ve Yorumlanması}

Yapılan literatür taraması sonucunda elde edilen veriler ışığında Neoliberal piyasa koşulları emek türlerinin yapısını radikal bir biç̧imde değişime uğrattığı görülmüştür. Emeğin fabrika duvarları dışına taşarak tüm şehre ve gündelik hayata yayılması ve aynı zamanda üretilen ürünlerin gittikçe soyut bir hale gelmesi emeğin analizinin de giderek zorlaşmasina neden olmuştur. Bu süreç beraberinde yeni emek türlerini yaratsa da pek çoğu gizlide kalmaktadır. Bu nedenle yeni emek analizlerine ihtiyaç duyulmaktadır. Bu noktada duygulanımsal emek/gayri maddi emek literatürü önem kazanmışır.

Bu çalışmada da söz konusu literatürün temel tartışmaları referans alınmıştır. Bu tartışmalardan hareketle serbest piyasa ve özelleştirme ilkelerine dayanan yeni Neoliberal döneme uygun olarak tüm emek ve çalışma hayatının yeniden yapılandığı ve çeşitlendiği görülmüştür. Ayrıca söz konusu değişimden sadece emek piyasasının değil aynı zamanda toplumsal, kültürel ve bireysel yaşamlarımızın da etkilendiği sonucuna varılmıştır. Bunun yanı sıra eldeki çalışma sonucunda konunun daha da farklı bir boyutu olduğu anlaşılmış ve yeni bir çalışmanın zorunluluğu gündeme getirilmiştir. Söz konusu yeni çalışmanın medya sektöründe rol alan çocuk oyuncular üzerinden Neoliberal birey olarak adlandırabileceğimiz girişimci, rekabetçi ve tüketici özneyi anlamamıza yardımcı olacağı düşünülmektedir.

\section{Sonuç ve Öneriler}

Bu çalışmanın sonucunda görülmüştür ki; serbest piyasa ve özelleştirme ilkelerine dayanan yeni ekonomik döneme uygun olarak tüm emek ve çalışma hayatı yeniden yapılanmış ve emek biçimleri çeşitlenmiştir. Ancak bu değişimden sadece emek piyasası değil aynı zamanda toplumsal, kültürel ve bireysel yaşamlarımız da etkilenmiştir. Söz konusu yeni dönem Fordizm sonrası kapitalizmin 'zaferi' ile taçlanan Neo-liberal ilkeler ve küreselleşmenin ekonomik niteliğinin birlikteliğinden oluşmaktadır. Pek çok çalışmanın ortak noktası bu gün gelinen noktada söz konusu bu iki fenomenin iç içe geçmiş halinin insani, kültürel, toplumsal ve ahlaki neticeleri üzerinedir (Özbay, Terzioğlu ve Yasin, 2011, s. 15). Dolayısıyla bu yeni olguyu sadece çocuk emeği bağlamında tartışmanın bize sınırlı bir analiz çerçevesi sunacağı düşünülmektedir.

Ayrıca söz konusu çocukların çalışmasını sağlayan yapının ve bu yapının bireylerin duygularında, isteklerinde, seçimlerinde ve genel olarak hayat1 değerlendirmelerindeki etkinliğinin neler olduğu sorusunun da altının çizilmesi gerektiğine inanılmaktadır. Bu yaklaşımdan hareketle çocuk oyuncuların sadece emek açısından değil ama aynı zamanda pek çok farklı açıdan analizinin yapılmasının günümüz kapitalizmini ve kapitalist bireyini anlamada önemli bir referans sağlayacağı düşünülmektedir. Dolaysıyla bu çalışma sadece bir çocuk emeği analizi yapmanın yanında konuyla bağlantılı başka bir çalışmanın da sorusunu sormakta ve konuyla ilgili yeni bir tartışma açmaktadır.

Bu yeni çalışmada Lazzarato'nun (2013, s. 5) da dediği gibi Neoliberalizm "piyasa" ve "toplum” kavramlarından ne anladıklarını açığa çıkarmak ve bunlar arasındaki ilişkiyi nasıl kavramsallaştırdıklarını bilmek için bahsi geçen çocuk oyuncuların değişik açılardan analizi yapılmalıdır. Neoliberalizm farklılaşmayı ve rekabeti teşvik etmekte ve tüm bireyleri "insan sermayesine" göre dönüştürmekte, kendi kendisinin girişimcisi haline gelmek üzere kışkırtmakta ve sınırlandırmaktadır (Lazzarato, 2013, s. 7). Dolayısıyla bir sonraki çalışmada medya sektöründe çalışan çocuklar Neoliberalizm dayattığı bu yeni kültüre uygun bireyler olarak ele alınmalı ve hem onlar hem de onları bu sektörde çalışmaları için teşvik eden ebeveynleri -ama özellikle anneleri- hatta onları izleyen toplumun geri kalanları kendi kendisinin girişimcisi bireyler olarak tartışmaya açılmalıdır.

\section{Etik Beyan}

"Çocuk Emeğinin Dönüşümü: Ev İçi Üretimden Film Setlerine” başlıklı çalışmanın yazım sürecinde bilimsel, etik ve alıntı kurallarına uyulmuş; toplanan veriler üzerinde herhangi bir tahrifat yapılmamıs ve bu çalışma herhangi başka bir akademik yayın ortamına değerlendirme için gönderilmemiştir.

\section{Kaynakça}

Akalın, A. (2007). Duygulanım ve duygulanımsal emek üzerine notlar. Birikim 217, 114-121.

Aykaç, H. B. (2016). Hukuksal açıdan çocuk ve genç işçiliği. Türkiye Barolar Birliği Dergisi 2015/116, 335-386.

Çelik, A. (2010). Çocuk işçiliğinin bitmeyen öyküsü. İçinde K. İnal (der.), Türkiye’de çocuk emeği (ss. 54-77). Ankara: Ütopya Yayınevi. 
Değirmencioğlu, S. M. (2010). Medyada çocuk emeği ve reklamların çocuk işçileri. İçinde K. İnal (der.), Türkijye'de cocuk emeği (ss. 313-329). Ankara: Ütopya Yayınevi.

Dikmen, A. (1998). Cocuk haklarna dair sǫ̈leşme çerçevesinde istanbul'da çallşan çocuklar üz̧erine bir değerlendirme (Doktora Tezi). Mimar Sinan Üniversitesi Sosyal Bilimler Enstitüsü, İstanbul.

Emirgil, B. F. (2010). Yeni kapitalizmde emeği sorunsallaştırmak: emeğin maddi-olmayan görünümleri. Çalısma ve Toplum 24(1), 221-238

Erder, S. (2010). Çalışan çocuklar: 'çırak mı?’, 'işçi mi? İçinde K. İnal (der.), Türkiye’de çocuk emeği (ss. 221-238). Ankara: Ütopya Yayınevi.

Ertürk, Y. (2010). Türkiye'de çocuk emeğinin kullanım biçimleri. İçinde K. İnal (der.), Türkijye'de çocuk emeği (ss. 2938). Ankara: Ütopya Yayınevi.

Fass, P. S., (2004). Çocuklar ve küreselleşme, N. Ahioğlu (çev.), Ankara Üniversitesi Eğitim Bilimleri Fakültesi Dergisi, 37(1), 141-155.

Hardt, M. (1999). Affective labor. Boundary 2, 26(2), 89-100. Erişim adresi:http:// www.english.ufl.edu/mrg/readings/Affective\%20Labor.pdf

Hardt, M. ve Negri, A. (2004). Çokluk: İmparatorluk çağında savas ve demokrasi (Çev: A. Yılmaz). İstanbul: Ayrıntı Yayınlar1.

Harvey, D. (2004). Yeni emperyaliẓm (Çev: A. N. Bingörl). İstanbul: Everest Yayınları.

Heywood, C. (2003). Baba bana top at! Batı'da çocukluğun taribi (Çev: E. Hoşsucu). İstanbul: Kitap Yayınevi.

İnal, K. (2007a). Modernizm ve çocuk: Geleneksel, modern ve postmodern cocukluk imgeleri. Ankara: Sobil Yayınlar1.

İnal, K. (2007b). Çocukluğun sosyal tarihi bazı değişkenler açısından genel bir değerlendirme. Toplum ve Hekim Dergisi 22(5), 324-343.

İnal, K. (2010). Sunuş. İçinde K. İnal (der.), Türkiye'de çocuk emeği (ss. 7-27). Ankara: Ütopya Yayınevi.

Kavili Arap, S. (2014). Neoliberal dinamikler açısından kentsel mekânda çocukluk. İçinde M. Şengül, T. Kaya (Yay. Haz.), Kapitalizm ve paternaližm kiskacında çocuke (ss.159-175). Malatya: Eğitim Sen Yayınları.

Lazzarato, M. (1996). Thought in Italy: A Potential Politics (Theoriy Out of Bounds), Radical. In P. Virno \& M. Hardt (Eds.). Immaterial Labour (ss. 133-150) Minnesota: University of Minnesota Prees.

Lazzarato, M. (2013). Neoliberalizm iş başında: Eşitsizlik, güvensizlik ve toplumsalın yeniden kurulumu. Politikekonomik alanın incelenmesi için temel öğeler, S. Yardımcı (Çev), skopdergi-Sayı 4.

Özbay, C., Terzioğlu, A. ve Yasin, Y., (2011). Giriş. İçinde C. Özbay Özbay, C., Terzioğlu, A. ve Yasin, Y. (der.), Neoliberalizm ve mabremiyet (ss. 9-28). İstanbul: Metis Yayınları.

Özgün, A. (2007). Kılçıksız emek, yağsız sermaye: gayrı-maddi emek tartışması. Birikim, 217, 31-45.

Rapport, L. J. ve Melen M. (1998). Childhood celebrity, parental attcahment, and adult adjustment: The young peformers study. Journal Of Personality Assessment, 70(3), 448-505.

Tekin-Yılmaz, T. (2014). Çocuk işçiliğinin yeni formları. Çalışma ve Toplum 40(1), 211-230.

Yıldırım, H. O. (2008). Dünyada ve Türkiye'de çocuk isscilï̈i ve özel bir örnek olarak Istanbul ilinde otomotiv kücük sanayiinde çalışan çocuk iş̧̧ ve çıraklar (Yüksek Lisans Tezi). Kadir Has Üniversitesi Sosyal Bilimler Enstitüsü, İstanbul.

Yücesan-Özdemir, G. (2014). Inatçı köstebek. İstanbul: Yordam Kitap

Yücesan-Özdemir, G. ve Özdemir, A. M. (2010). Türkiye'de çocuk emeği ve sosyal politika: Alternatifi düşünmek için egemen söylemin eleştirisi İçinde K. İnal (Der.), Türkiye'de çocuk emĕgi (ss. 133-159). Ankara: Ütopya Yayınevi.

\section{EXTENDED ABSTRACT}

Use of child labour is a phenomenon that has been observed in diverse societies and historical periods. Having assumed first an active role in household production, the children started to work at different jobs in accordance with the needs of the changing economic conditions. In addition to their responsibilities at home, the children provided the household economy with serious contributions through various means of subsistence of the family. It is well-established that the girls were considered responsible for the general housekeeping duties beginning from the middle ages and supported the reproduction of the household in almost each field of responsibility from cooking to washing the dishes, from bread making to washing clothes and taking care of younger siblings, if mother leaves home for work. Besides, children work in agricultural fields, vineyards, orchards, and husbandry that could be considered the main means of subsistence of the family and work as apprentices at small workshops. Therefore, it is hard to understand on which fields there was an intensive use of child labour during that period.

As stated above, although children have worked or have been employed in almost all the periods, the needs of the economic conditions of the day added new ones to their existing jobs. Having worked during the Middle Ages in generally home-based jobs based on manual labour that were relatively appropriate for their ages, the children started to be employed in factories together with the industrial revolution. Work and education were intertwined throughout the periods preceding the industrial revolution and that in fact the function of child employment was also to pass the craft to the next generations. 
However, there rose a need for a plenty of workers together with the establishment of factories upon the industrial revolution and thus children were involved in the capitalist production as more obedient and submissive individuals open to exploitation. Besides, the fact that families were in serious poverty was another reason for child employment in factories. The children and women left households and small workshops and volunteered to work at factories because their families were failing to sustain subsistence levels. Thus, previously barely recognised and valued child labour was recognized and the child labourer category was mentioned following the

This period was marked with the fact that children, and especially the poor and orphan children were seriously oppressed and exploited by the capitalist mode of production. Nevertheless, the place of children in the society started to change under influence of the Renaissance and Reform movements that were forming and transforming the society in the same period. Those approaches paved the way for the idea that especially the middle- and upper-class children's place was the school. Therefore, once shaped by the religion within the narrow and restrictive relations of the community and seen as a labour source at production fields, the children started to be considered a psychological (compassion) resource other than an economic one. Thus, children were more attentively taken care of and formed by knowledge in the middle- and upper-class families together with urbanisation and industrialisation. Accordingly, the children were placed in a sphere of innocence by the 19th century and considered as individuals who needed to be educated for the future via schools and to be invested upon. Nevertheless, it is important to note that this was rather relevant for the western societies.

By the 20th century, another path emerged in the labour market and thus in the perception of child labour in line with the changes in the capital market. The excessive capital accumulation seen especially in the American and European economy by the 1970s, a new economy-politic approach based on removing the obstacles so that capital can be invested globally was started to be proliferated throughout the world by IMF and the World Bank. During that period the power balance between the capital and labour was reestablished, and the individual capitalists were equipped with new powers in disfavour of the workers, including primarily recruitment and dismissal and the work hours and duration. As a result, the market institution as a means of oppression became, where the entirety of the society, and especially the children as the most vulnerable, the most obedient, and the most submissive labour force, were shaped in line with the requirements of the new capital relationship.

Furthermore, beginning from the 1970s, production went beyond the boundaries of factories and has become a type of labour that produces not only tangible goods but also such immeasurable assets as services, information, and communication. It has been suggested that this type of labour, called as intangible labour, not only produces good but at the same time the societal relations. The affectional labour that can be considered a form of intangible labour is another form of labour that needs to be addressed in that period. This is because of the fact that such form of labour started to produce knowledge, information, communication, relations, and affectional expression along with tangible goods by especially the last decade of the 20th century. The said form of labour, which even cannot be conceived as labour, has also a structure based on arbitrariness, mobility, and hierarchy due to the fact that the capitalist employer holds the power to arrange the working hours to its benefit. The recent changes in the labour processes naturally paved the way for the changes occurred in the field of child labour.

Media, as an indispensable element in a capitalist socio-economic system, led to formation of a new form of child labour in certain centres of the world. The labour market as changed with globalisation and neoliberalism resulted in the intensive use of child actors and actresses in the media sectors located at certain centres of the world, such as Istanbul, and thus a new job was added to the existing jobs of the children.

Although there are TV series shot in Ankara, such examples do not amount to a level that could change the central position of Istanbul. Due to the fact that advertisements, TV series, and films are generally shot at Istanbul, that the advertising agencies that provide the sector with labour force are located in Istanbul, and thus Istanbul is the centre of the film industry, created a form of labour specific to Istanbul. Nevertheless, the child actors and actresses, which appeared on the agenda together with the gradual proliferation of media and TV due to the rise of capitalism, cannot be defined as employees or considered as such due to the particular character of the job performed by them. Therefore, in order to understand the child labour today, it is imperative to involve the aforementioned child actors and actresses in the Istanbul labour market and mention in relation to the said market. 